\title{
The introduction of public-private partnerships in the Netherlands as a case of institutional bricolage: The evolution of an Anglo-Saxon transplant in a Rhineland context
}

\author{
Joop Koppenjan ${ }^{1} \odot \mid$ Martin de Jong ${ }^{2}$
}

${ }^{1}$ Department of Public Administration and Sociology, Erasmus University Rotterdam, Rotterdam, The Netherlands; and School of Business and Hospitality, Southern Cross University, Lismore, Australia

${ }^{2}$ Faculty of Technology, Policy and Management, Delft University of Technology, Delft, The Netherlands; School of International Relations and Public Affairs, Fudan University, Shanghai, China; and Erasmus Law School, Erasmus University Rotterdam, Rotterdam, The Netherlands

Correspondence

Joop Koppenjan, Erasmus University

Rotterdam, PO Box 1738 3000DR Rotterdam,

The Netherlands.

Email: koppenjan@fsw.eur.nl

Funding information

Dutch Research Council (NWO), NSOB,

Deltares, RebelGroup, ResetManagement, Twynstra Gudde, and Rijkswaterstaat, Grant/ Award Number: NWO-project number 40914-014; Additional support was received from the Delft Initiative for Mobility \& Infrastructures (DIMI).
In this contribution, the introduction of contractual public-private partnerships (PPPs) in the Netherlands, more specifically the use of Design, Build, Finance, Maintenance, and Operations (DBFMO) contracts in Dutch infrastructure management, is analysed using a specific strand within the policy transfer and institutional transplantation literature: that of 'institutional bricolage'. This perspective states that policy transplants come to fit their new institutional context stepwise. This contribution reconstructs the adoption process by which the Anglo-Saxon-inspired PPP practice is incorporated into the traditional 'Rhinelandic' practice of infrastructure management in the Netherlands, identifying four waves of PPP initiatives. It concludes that these waves and the difficulties that emerge in them stem from an ongoing struggle between actor coalitions, one aiming to preserve the transplant in its original shape, and others making attempts at bricolage. Shifts in power relations explain the progress and outcomes of the process of institutional transplantation.

\section{1 | INTRODUCTION}

The UK has played a pioneering role in the development of public-private partnerships (PPPs) as a practice of procurement and management of public infrastructure. The Private Finance Initiative (PFI) model was developed by the Conservative government in the UK in the early 1990s. It has undergone various updates under the name of PPP and PF2 since then, and has evolved into an important standard of PPP practices worldwide (Osborne 2000; Spackman, 2002; HM Treasury 2012). Among other countries, Australia, New Zealand, Canada, South Africa, Finland, Belgium and the Netherlands have set up programmes that build on the UK example, introducing UK-inspired 
contractual partnership, governed by Design, Build, Finance, Maintenance, and Operations (DBFMO) contracts and the accompanying toolbox with instruments such as standard procedures for procurement, contract management, and assessment (e.g., the public-private comparator and the private sector comparator). Contractual PPP can be distinguished from institutional PPP, in which public and private collaboration takes the shape of an alliance, often institutionalized by the establishment of a public-private joint venture (Hodge et al. 2010).

Although the UK remains the leading country in the application of this type of PPP, the Netherlands has proved to be one of the most committed followers of the UK example. In 2016, 37 national infrastructure projects were being realized using $\mathrm{DBFM}(\mathrm{O})$ contracts, with a total value of $€ 13 \mathrm{bn}$ and a realized added value of $€ 1.5 \mathrm{bn}$ (Ministry of Finance 2016).

The introduction of UK-style PPPs in the Netherlands is remarkable, as contractual PPPs originate in an AngloSaxon environment where contractual relationships in infrastructure development are far more prominent than in continental Europe. The Netherlands has a long tradition of collaborative relations between partners in the public, private, and civil society sectors, a tradition otherwise known as the 'Rhinelandic model', which characterizes relationships in North-Western Europe (Albert 1991; Koppenjan et al. 2010; Van Putten 2013). Seen in this light, the introduction in the Netherlands of the PFI-inspired practices of contractual PPP, characterized by the use of $\operatorname{DBFM}(\mathrm{O})$ contracts, ${ }^{1}$ can be viewed as a specific example of cross-national policy transfer (Dolowitz and Marsh 1996, 2000; De Jong et al. 2002; James and Lodge 2003; Evans 2009; Benson and Jordan 2011).

The contribution that this article aims to make is to examine this adoption process: how did contractual PPP as an alien institutional transplant succeed in nesting itself in the bosom of Dutch Rhinelandic infrastructure development, to what extent did bricolage occur in this process, and how did this process affect Dutch PPP practice over time? Reconstructing this adoption process will increase our understanding of how and why PPP evolved in a nation with different governance traditions, but also offer lessons for the transfer of $\mathrm{DBFM}(\mathrm{O})$ and other institutional practices to other countries and show the added value that the institutional bricolage perspective brings to the policy transfer literature.

To conduct this reconstructive analysis, section 2 briefly introduces the policy transfer and institutional transplantation literature, positions the institutional bricolage perspective within this broader literature, and clarifies how it can be applied to the case at hand. Next, section 3 describes the nature of contractual PPP and narrates the history of its adoption in Dutch policy practice; it does so by distinguishing four waves in its adoption. Section 4 then analyses each of the four waves in more depth, using the institutional bricolage perspective in order to establish the extent to which bricolage occurred and how this influenced the process of the introduction of contractual PPP in the Netherlands. To conclude, section 5 lists the main findings from this article and presents conclusions regarding the potential added value of the institutional bricolage perspective for the policy transfer literature and the broader implications of this case for PPP policies and other practices of institutional transplantation in general.

The reconstruction of the evolution of PPP in the Netherlands is based on two main sources. The first is an analysis of the sizeable collection of reports, policy documents, and progress reports published by central government agencies, various advisory committees, and the Dutch Audit Office. Second, we used academic works as secondary sources, especially publications in the period 1988-2016 in the field of public policy, public administration, and governance studies.

\section{2 | POLICY TRANSFER AND INSTITUTIONAL BRICOLAGE}

Policy transfer was defined by its nominal intellectual heirs Dolowitz and Marsh (1996, p. 344) as 'a process in which knowledge about policies, administrative arrangements, institutions, etc. in one time and/or place is used in

\footnotetext{
${ }^{1}$ As the Dutch agency Rijkswaterstaat is responsible for the operation of road and water infrastructure, roads and water projects commonly use DBFM contracts, whereas DBFMO contracts are used in the management of public buildings, a responsibility of the agency Rijksgebouwendienst (later: Rijksvastgoedbedrijf). In this article, we use the term DBFM(O) contracts, referring to both types of contract.
} 
the development of policies, administrative arrangements and institutions in another time and/or place'. The concept has over time been both empirically and theoretically expanded and become commonly recognized in the political and policy sciences (Evans and Davies 1999; Dolowitz and Marsh 2000; Lodge 2002; James and Lodge 2003; Stone 2017; Evans 2009; Benson and Jordan 2011; Marsden and Stead 2011). Although the usefulness of the concept is undisputed in demonstrating the administrative process of who learns how and when from whom abroad, about what is good practice or a promising policy model or programme, doubts have emerged regarding the analytical clarity of the concept on a number of counts. It is, for instance, hard to distinguish policy transfer from other types of policy-making (James and Lodge 2003; Benson and Jordan 2011). The concept of policy transfer takes insufficiently into account how adopting policy actors remould and retranslate concepts and ideas (Stone 2017). Also, the concept tends to downplay the complexity and impact of path-dependent institutional traditions and dominant practices among policy actors on the way in which transplants are, or are not, transferred and reshaped (Knill 2001; de Jong et al. 2002; Lodge 2002).

Although we agree with all three criticisms, given the topic of this contribution and the level of analysis required, our main focus is on dealing with the third point: the institutional aspect. De Jong (1999) has coined the concept 'institutional transplantation' as a particular strand within the policy transfer literature that pays specific attention to the institutional hurdles that exist in the adoption of policy ideas, models, programmes, and regulations from abroad (de Jong 2013). He pointed specifically to the existence of a global variation in cultural, legal, political, and administrative families of nations that make institutional congruence in the adoption of foreign transplants an important issue. De Jong et al. (2002) subsequently further developed the concept and introduced two different, but potentially complementary, perspectives for understanding this congruence.

The first perspective states that successful transfer or transplantation requires institutional goodness of fit between the donating and the adopting constituency. This implies that, if a transplant is adopted from a different cultural, legal, political, or administrative family of nations (a so-called like-to-unlike transplant), the transplant may be rejected by the adopting system or conversely overwhelm and jeopardize the proper functioning of the system, because of the incompatibility of underlying governance assumptions and accompanying practices.

In contrast, the second perspective states that successful transfer or transplantation requires a process of creative institutional bricolage in the interaction among policy actors in their adoption process. In this process, structural incongruence can potentially be overcome through constructive negotiations among policy actors remoulding the original in such a way that it is seamlessly incorporated into its new institutional environment, even if this has different features from those of the donor nation. Here, policy actors attribute meaning to and negotiate the adoption of the transplant and can be said to effectively create something new. Other authors have emphasized that bricolage is in fact part of the process of policy translation, constituting a starting point for innovation in which negotiation, mutation, and transformation result in the indigenization of policies over time (Parrado 2008; Lendvai and Stubbs 2009; Stone 2017). Rather than leading to abrupt breakthroughs in the reform of institutional structures at critical junctures, most adoptions occur through incremental changes that over time accumulate into gradual, but significant, institutional transformation (Streeck and Thelen 2005; Thelen 2009). The morphology of institutional bricolage, therefore, is one of grafting new institutional layers over previous ones, hybridization and synthesis rather than outright displacement: actors use bits and pieces of previously attempted models and parallel paths to assemble new institutional arrangements (Campbell 2004, 2009; Streeck and Thelen 2005).

Consequently, even if a lack of goodness of fit makes the adoption of a foreign-inspired policy more complicated and risky than a transplant within the same family of nations (a like-to-like transplant), these hurdles may well be overcome if compatibility is realized through constructive tampering and renegotiation among the actors in the adopting policy network: institutional bricolage. In what follows, we examine what this process of institutional bricolage looked like in the case of the like-to-unlike transfer of contractual PPP from the United Kingdom to the Netherlands. We do this by first describing the above-mentioned four waves in which PPP was adopted (section 3). Each of these waves can be seen as a step in the overall institutional transplantation process, the adoption process by which PPP was institutionalized in the Dutch context. Institutionalization is the process by which a new or foreign 
policy, idea, belief, rule or institutional practice is embedded in an organization, social system or society as a whole (compare Streeck and Thelen 2005 and Lowndes and Roberts 2013). In this contribution, institutionalization refers to the initiation and realization of PPP projects and adaptations of the institutional context that the introduction and management of these projects require.

The waves are distinguished on the basis of the progress the institutional translation process made. In the first wave initiatives were unfocused and failed. After this false start, in the second wave attempts were more focused, but only few PPP contracts were signed. In the third wave the adoption process gained momentum, since a number of PPP projects were initiated. In the fourth wave more projects were started, the first projects reached the operation and maintenance phases, but problems due to a lack of goodness of fit also became apparent.

Next, for each of these waves, we dissect whether and how the involved policy actors interpreted and reshuffled the original policy ideas, to what extent this resolved the incongruence between the transplant and the existing practices of the institutional environment, and how this contributed to the institutionalization of this new practice of contractual PPP in the Netherlands (section 4).

\section{3 | THE INTRODUCTION OF PPP IN THE NETHERLANDS: FOUR WAVES}

Contractual PPPs can be seen as an innovative form of collaboration between public and private parties, in contrast to traditional ways of project realization, by (re)allocating responsibilities in such a way that private parties bear financial risks that create incentives for realizing collaborative advantages and added value (compare Osborne 2000; Ghobadian et al. 2004; Bult-Spiering and Dewulf 2008).

Contractual PPPs as gradually introduced in the Netherlands predominantly took the shape of projects governed by $\operatorname{DBFM}(\mathrm{O})$ contracts. These contracts were different from traditional public procurement because of their focus on the specification of project outputs rather than on detailed project designs, a greater risk transfer to the private sector (especially financial risks), long-term contracts, and the integration or bundling of different functions into one single contract (Grimsey and Lewis 2004; Hodge et al. 2010). The contract provided government with a steering mechanism to ensure that the private parties performed. Payments were dependent on performance, which was defined in the contract; non-performance or underperformance resulted in payments not being made or in sanctions. During the contract, performance was monitored (Dutch Audit Office 2013, p. 4).

At the state level in the Netherlands, the Ministry of Infrastructure and the Environment (prior to 2010 the Ministry of Transportation) and the Ministry of Internal Affairs (prior to 2010 the Ministry of Housing) were responsible for decisions on the construction of public infrastructure (roads and waterworks and public buildings, respectively). Their related agencies Rijkswaterstaat (for roads and waterworks) and Rijksvastgoedbedrijf (for public buildings; before 2014 Rijksgebouwendienst) were responsible for the actual construction and maintenance. The Ministry of Finance was an important actor given the public expenditure needed to realize and maintain these projects.

In the following subsections, the evolutionary process by which PPP was introduced in the Netherlands is reconstructed by describing the institutional transplantation process during four waves of activities.

\section{1 | The first wave (1986-97): the first transplantation attempt strands}

In the 1980s, the second Lubbers Cabinet (1986-89), a coalition of the Christian Democratic Party and the LiberalConservative Party, developed policies to overcome the impact of an economic crisis that was plaguing Western economies at that time. Infrastructure projects were seen as a way to propel economic growth, even at a time when public budgets were limited. In the UK, the government headed by Prime Minister Thatcher had succeeded in attracting private sector parties to finance the construction and maintenance of public buildings and infrastructure. Following this example, in 1986 the coalition agreement stated that, in the Netherlands, new forms of publicprivate cooperation aimed at encouraging private sector investment in public infrastructures would be established. 
In various policy documents, the potential for using private financing and PPPs to build public infrastructure was mentioned (Klijn 2009).

In the period between the late 1980s and the early 1990s, the first large-scale PPP projects in the Netherlands were realized. Two road tunnels, the Wijkertunnel (construction completed in 1996) and the tunnel under the river Noord (completed in 1992), were financed by private banks. Actually, these tunnels were realized by traditional contracts with private consortiums, financed by banks. The private consortiums were allowed to recoup their investments by a so-called shadow toll mechanism, the government making payments on the basis of the number of cars using the tunnels over a 30-year period. As the use of cars increased dramatically over recent decades, these tunnels resulted in excessive profits for private parties. The 1995 Dutch Audit Office report revealed that these projects proved to be, respectively, 41 per cent and 21 per cent more expensive than if they had been realized with public funding. This resulted in a ban on PPP for road construction for quite some time (Van Ham and Koppenjan 2001). Currently, the extra costs are estimated to be even higher (Dutch Audit Office 1993; Van der Schot et al. 2003; Eversdijk and Korsten 2015).

All in all, during this first PPP wave, the expectations were that private parties would contribute to the funding of public projects. No clear ideas existed on what type of arrangements and contracts were needed. Overall, the outcomes of these first experiments were close to disastrous and resulted in PPPs being discredited as an instrument for many years (Van Ham and Koppenjan 2001; Koppenjan 2005).

\section{2 | The second wave (1998-2003): first institutional strongholds established}

In 1998, PPP was rehabilitated by the Second Kok Cabinet (a coalition of the Social Democratic Party and the Liberal-Conservative Party), which mentioned PPP in its coalition agreement. The agreement stated that the aim was a controlled enlargement of the use of PPPs in the Netherlands. The knowledge, expertise, and experience required were to be combined in a knowledge centre, as suggested in the 'More Value through Collaboration' report (Klijn 2009; also see Knowledge Centre PPP 1998).

This report was conceived by a commission initiated by the Ministry of Finance. The commission had studied experiences with PPP in other countries and formulated conditions for successful PPPs. In the report, a number of projects suitable for involving private parties (among which so-called low hanging fruit) were mentioned; for instance, the construction of the A4 highway between Delft and Schiedam, the extension of the Port of Rotterdam, the realization of two large railway projects (the Betuwe line and the high speed railway to Paris), and the development of various high speed railway stations. Private companies also proposed projects: the construction of a second national airport, a magnetic levitation train, and an underground logistics system between Schiphol airport and the flower auction in Aalsmeer.

Apart from discussing financial instruments and possible contractual arrangements, the report also paid a lot of attention to managing the collaboration process (Knowledge Centre PPP 1998). This attention to the 'soft side' of PPP subsequently disappeared in the PPP approach propagated by the Ministry of Finance. As announced, in 1999 the Knowledge Centre PPP was established as part of the Ministry of Finance. This centre advised government on policies to promote PPP, developed instruments and standards for PPP contracts, and offered advice and support to specific PPP projects. In doing so, the Knowledge Centre was strongly inspired by the UK's PFIs, promoting instruments such as market explorations, the public-private comparator (PPC) and the public sector comparator (PSC) (both ex-ante evaluation tools to calculate the added value of PPP), and contractual arrangements, more specifically a standardized DBFM(O) contract. A number of projects were assigned to be organized as PPPs in the areas of transport infrastructure, urban development, green infrastructure, and knowledge development.

Over the next few years, it proved difficult to realize PPPs. Some of the selected projects were cancelled altogether. Others were realized in a traditional fashion. The superstructure of the high speed railway line was contracted out as a DBFM, and the private involvement in the Betuwe line stagnated. High speed railway stations were developed in traditional ways. As far as road projects were concerned, three projects were realized in this period 
using a contractual PPP (A59, N31, N201). In Delfland, a PPP contract for the construction and operation of a water purification plant was signed in 2002 (Koppenjan 2005).

In the reports published by the Knowledge Centre in this period, it was increasingly recognized that progress towards developing PPPs was stagnating. It was stated that the high expectations for PPPs were not always justified and that the actual processes of tendering and contracting were time consuming. Progress was hindered by public actors not always supporting private involvement, by the difficulty of defining clear and functionally specified output criteria, by decisions to realize a project taken before private involvement was achieved, and by the late involvement of private parties in projects (Knowledge Centre PPP 2001, 2002). In the following years, the argument that the number of PPP projects was too low grew stronger. Without a larger deal flow, it would be hard to develop standards and to reduce the transaction costs for the parties involved (Knowledge Centre PPP 2004; Klijn 2009).

Overall, it can be stated that, during the second wave, PPP was pursued in a more prudent and informed way. Expertise and instruments were developed, and the approach to PPPs acquired a recognizable shape, aimed at $\operatorname{DBFM}(\mathrm{O})$ contracts following the formats as developed in the UK. Nevertheless, the number of projects realized was still limited.

\section{3 | The third wave (2004-10): the institutional transplantation takes off}

From 2004 onwards, attempts were made to accelerate PPP development in the field of public buildings, transport, and water infrastructure. In 2005, a PPP taskforce established by the Ministry of Transport, consisting of public and private parties, identified three main barriers: the high transaction costs for $\operatorname{DBFM(O)}$ contracts, the fact that due to the limited number of PPP projects no experience had been gained, and the fact that the detailed project definitions drafted by the government did not allow private parties to come up with new creative ideas (Ministry of Transport 2005).

Consequently, the Ministry came up with a standard DBFM model contract, accompanied by a standard procurement procedure. The aim was to use functional performance criteria instead of detailed project definitions and to allow private parties to come up with new ideas during the tendering phase. Eventually, this resulted in the standard use of the competitive dialogue procedure to tender for $\mathrm{DBFM}(\mathrm{O})$ projects as prescribed by the European Union (Hoezen 2012). In this procedure, competing consortiums are asked to develop project ideas based on functional criteria set by the government, and they receive financial compensation if their design is not selected. While competitive tendering forbids communication, this procedure allows for various rounds of communication between the government, competing consortiums, and stakeholders during the tendering process. This procedure accords with the culture of consultation and negotiation that characterizes the Rhineland tradition of collaboration in the Netherlands.

At this time, the Cabinet also introduced the obligation to perform a PPC with regard to infrastructure projects that required an investment of over 112.5 million euros and buildings of over 25 million euros. A PPC is an ex-ante evaluation of the added value of a PPP compared to the traditional (public) realization of the project. If the PPC indicates that added value can be realized, a $\operatorname{DBFM}(\mathrm{O})$ contract should be used. In an attempt to further institutionalize PPPs, in 2006 the Cabinet abolished the Knowledge Centre at the Ministry of Finance, and the various ministries, especially the Ministry of Defence (responsible for military buildings and systems), the Ministry of Housing (responsible for the construction of public buildings and physical planning projects), and the Ministry of Transport (responsible for transport and water infrastructure) were required to develop their own PPP practices. The Ministry of Finance remained responsible for PPP policy as a whole, but the implementation of individual PPP projects became the responsibility of the ministries directly involved. In 2004, Rijkswaterstaat adopted the motto 'Market, unless': it decided to use PPP as a standard working procedure. It established its own PPP expertise centre. This led to a radical internal transformation of the Ministry: new ways of working were introduced and staff with new skills and expertise were recruited. 
In 2007, the Ministries of Finance and Transport established yet another commission in order to speed up the development of PPP projects. This commission, the Private Financing of Infrastructure, emphasized the need for a larger deal flow in order to reduce transaction costs, to increase experience and continuity, and to obtain stronger political commitment. The aim was to accelerate the realization and volume of public infrastructure and to generate added value. It advised the government to lower the threshold value for obligatory PPCs from 112.5 to 60 million euros. The Cabinet followed this advice quickly (Commission for Private Financing of Infrastructure 2008).

In this period, a number of new projects were added to the list of DBFM(O) projects: road projects such as the A12 Lunetten-Veenendaal, the A15 Maasvlakte-Vaanplein, the second Coentunnel near Amsterdam, and building projects like the renovation of the Ministry of Finance, the construction of a new tax office in Doetinchem, and the reconstruction of a military base (the Kromhout barracks).

\section{4 | The fourth wave (since 2011): the institutional transplantation process widens, deepens and experiences setbacks}

In 2011, the new Cabinet Rutte I stated that it would pursue DBFM(O) contracts in as many projects as possible, giving the development of PPP yet another boost. New projects were put forward in transport and water infrastructure and public buildings. The Ministry of Safety and Justice was asked to explore the possibility of using DBFM(O) contracts in the building of detention centres. The Cabinet also planned to encourage the use of DBFM(O) contracts among local governments. In 2012, the PPP support office was established for this purpose (Ministry of Finance 2014).

In this period, as indicated in the Cabinet's vision, various new DBFM(O) projects were initiated. By the end of 2012, 13 DBFM(O) projects were being implemented, at a value of 6 billion euros and an expected added value of 800 million euros (Dutch Audit Office 2013). Eversdijk and Korsten (2015) stated that, although the PPC instrument was applied, this did not automatically result in projects with potential for added value being effectively developed as DBFM(O) projects. They examined 32 projects for which a PPC was carried out in the period 2000-11. According to the outcomes of the PPC studies, 23 of these projects were considered suitable for a $\operatorname{DBFM(O)}$ contract. Despite these outcomes, nine projects (40 per cent) were nevertheless not procured as DBFM(O) projects. The authors found that officials had various motives for reneging on a DBFM(O)contract, like time pressure, the limited scale of the maintenance task, the absence of expertise on $\operatorname{DBFM}(\mathrm{O})$ contracts, and high transaction costs. $\mathrm{DBFM}(\mathrm{O})$ contracts were not accepted uncritically, and many still considered it inappropriate to use these contracts.

Although the Ministry of Finance claimed that $\operatorname{DBFM(O)}$ projects realized agreed upon outcomes within time and budget (Ministry of Finance 2014), the actors involved found it hard to adapt to the new roles that were expected of them. Delays occurred in a number of building projects (Ministry of Finance 2016). In some projects, serious conflicts emerged between government and consortiums. Often these conflicts revolved around interpretation of the contracts regarding the allocation of unforeseen costs (Dutch Audit Office 2013; Reynaers 2014). Such conflict jeopardized the collaboration during the construction of the second Coentunnel. Cost overruns during the realization of the complex A15 project brought constructor Ballast Nedam to the edge of bankruptcy. The attitude of the government, not providing a helping hand, aroused anger on the builders' part. Another problem in the A15 project stemmed from the role division chosen: the consortium was responsible for stakeholder involvement. In this project, the stakeholders were the various municipalities located in and around the highway, their residents, and interest groups such as businesses and nature development and environmental groups, including the Rotterdam Port Authority. As the consortium had milestones for realizing performance targets, it had incentives to economize and to select cheaper solutions, not in line with the preferences of stakeholders (Verweij 2015). In general, it was concluded that the government's DBFM(O) projects transformed into so-called fight projects (Verbraeken and Weissink 2014). On the other hand, some $\operatorname{DBFM}(O)$ projects, such as the $A 12$ Lunetten-Veenendaal, were widely seen as a clear success. 
Also in this period, the first PPP projects entered the operation and maintenance phases, as was the case in for instance the renovation of the Ministry of Finance office building (Reynaers 2014). No experience was available on how to manage these phases, resulting in misunderstandings, disagreements and delays (Ministry of Finance 2016).

In 2013, the Dutch National Audit Office published the findings of its research on the implementation and contract management of DBFM(O) projects (Dutch Audit Office 2013). The Audit Office concluded that, although government claimed to have realized added value with the DBFMO contracts, this claim was incorrect because it would only be possible to determine whether the added value actually was realized at the end of the contract period of 15-30 years, depending on implementation. The Audit Office concluded that the contracts were clearly specified and most of the payments indeed were based on performance. However, it also found that the government often did not apply sanctions in the case of shortcomings because it was important to maintain a good relationship with the consortium. Another problem identified by the Audit Office was the large number of contract changes, leading to additional costs for the government. The Audit Office stated that contract management should be more firmly focused on preventing the occurrence of contract changes in order to control costs.

In 2016, in an attempt to reverse the adversarial relationships that had turned a number of DBFM(O) projects into fight projects, public and private parties signed a document to commit themselves to a new market vision that would underlie PPP from then onwards. They thereby expressed the intention to refrain from opportunistic behaviour and adopt a collaborative attitude, realize quality, and price realistically. The various ministries made this new market vision part of their policies, acknowledging the need for collaboration, while preserving a business-like attitude towards the performance of private parties and an unchanged commitment towards safeguarding competition in the market and the use of the contracts and instruments as developed (Rijkswaterstaat 2016; Minister of Infrastructure and the Environment 2016; Ministry of Finance 2016).

In the progress report on DBFMO projects in 2016/17, the Ministry of Finance (2016) states that, in general, $\operatorname{DBFM}(\mathrm{O})$ processes have been realized within budget, on time, and with the requested output. It also states that, thanks to the quality and consistency of the Dutch DBFMO policy, its focus is on value for money, standardization, and realizing a sufficient flow of deals. Its pragmatic orientation is also important: PPP is not a goal, but a means. This implies that other contract forms were to be chosen when needed. A number of complex projects such as the South Axis (a major road and train corridor near Amsterdam) will not use a DBFM contract, given the flexibility and collaboration required. The report announces an update of standardized bidding procedures, contracts, and a set of guidelines for all central government projects. New key performance indicators to assess performance will be introduced. Building on the Audit Office report, the report also emphasizes the standardization of contract management in the realization and operation phases. Besides this stress on the 'hard side' of DBFM(O), the report underlines the importance of learning from experience among various parties. This learning is not simply about training on how to use standard procedures as developed at central level, but also about facilitating the exchange of experiences in specific projects in a bottom-up manner. The report further suggests that the development of standards will allow for input from other participants.

The report also presents an overview of all DBFMO projects in their various phases, including the list of new projects up for DBFMO contracts. In particular, a growing number of projects are foreseen in the field of infrastructure (Dutch Audit Office 2013). This reveals the magnitude of the challenge that this ministry will face in terms of resources and skills. Whereas initially the ministry managed on average one DBFMO procurement procedure per year, in the coming years it will have to manage various procedures simultaneously. Table 1 gives an overview of the DBFM(O) projects realized in 2016 (Ministry of Finance 2016).

In the fourth period, the DBFMO practices evolved further, not only through the introduction of new projects, but also through projects reaching their maintenance and operation phases. Besides successes being realized, problems and conflicts became apparent, resulting in a shift in attention to the softer side of PPP. Within PPP policy, the emphasis on further standardization, new instruments, and value for money continues, while at the same time the need for collaboration, tailor-made solutions, and learning is increasingly acknowledged. 
TABLE 1 DBFM(O) projects in Dutch infrastructure in 2016

\begin{tabular}{lllll} 
Project phase & Roads & Water (Sluices) & Buildings & Total \\
\hline Operation & 6 & - & 10 & 16 \\
Construction & 6 & 5 & 5 & 16 \\
Decision-making & 4 & - & 1 & 5 \\
Total & 16 & 5 & 16 & 37 \\
\hline
\end{tabular}

Source: Ministry of Finance 2017.

\section{4 | BETWEEN GOODNESS OF FIT AND BRICOLAGE; THE POLITICS OF INSTITUTIONAL TRANSPLANTATION}

In this section, we use the institutional bricolage framework to analyse the four waves in the introduction of PPP in the Netherlands: to what extent did attempts to introduce PPP in the various periods reflect the original AngloSaxon ideas and can indications of bricolage be found, such as attempts to adapt the transplant to Rhinelandic practices of collaboration and soft management? And how did this influence the outcomes realized in these periods?

\section{1 | Wave 1: absence of goodness of fit and failed bricolage}

The introduction of PPP in the 1980s can be understood as a politically inspired top-down project by which a new Anglo-Saxon practice was implemented in an institutional context that lacked the required knowledge, skills, and expertise. This can be seen as a classic example of an institutional misfit. At the same time, some bricolage occurred; the projects were realized in a traditional way, with private finance as the only new element. In addition, a shadow toll arrangement was chosen to adapt the financial mechanism to the Dutch context, where the nature of the network does not allow for toll roads, given the many alternative routes available to car drivers. It can be argued that it was precisely these attempts at bricolage that caused the failure: the traditional contract with constructors did not allow for the creation of added value and the shadow toll arrangement with the banks was awkwardly negotiated, turning the project into a zero-sum game, with government as the losing party. This mix of institutional misfit and failed bricolage resulted not only in a counterproductive outcome, with private financing resulting in much higher public expenditure, but also in the discrediting of PPP altogether, once the Dutch Audit Office revealed the financial implications of the tunnel projects in 1993 (Dutch Audit Office 1993).

\subsection{Wave 2: a shift away from bricolage}

During the second wave (1998-2003), a shift occurred from a collaboration-oriented approach, as suggested in the 'More Value through Collaboration' report of 1998, to a strongly finance-oriented Anglo-Saxon interpretation of PPPs. This is largely due to the fact that the Ministry of Finance became responsible for the introduction of PPP. The Ministry of Finance is one of the few ministries in the Netherlands that have not developed networked relationships with societal parties involved in the implementation of policies at the local level, which are seen as typical of Rhinelandic practices (Van Putten 2013). In an attempt to introduce PPP practice in an informed way, the Knowledge Centre at the Ministry of Finance developed standards based on experiences and ideas as developed in AngloSaxon countries and especially the UK, like $\operatorname{DBFM}(\mathrm{O})$ contracts, guidelines, and instruments such as the PPC and the PSC. As a knowledge centre, it functioned as a partisan promotor of these practices, trying to impose them on other parts of the central government, like the Ministries of Transport and Housing, and the agencies Rijkswaterstaat and Rijksgebouwendienst, all involved in networked practices with constructors, lower levels of government, and other local stakeholders.

During this wave, the discretionary room for bricolage diminished, and there was a growing misfit between the institutional practices of PPP as promoted by the Knowledge Centre and the preferences and the standing practices 
of those within government involved in the development and management of concrete infrastructure projects. Unsurprisingly, during this wave the number of PPP deals realized remained limited, not only because of a lack of expertise and skills, but also because of reduced willingness and a missing sense of urgency (Eversdijk and Korsten 2015).

\subsection{Wave 3: institutionalization and bricolage go hand in hand}

During this period (2004-10), a next step was taken in the institutionalization of PPP in the Netherlands. The Anglo-Saxon perspective on PPPs progressed through the establishment of various PPP taskforces in 2005 and 2007 and the obligation to perform PPCs. These moves were attempts by the politically supported coalition led by the Ministry of Finance to force reluctant ministries to use PPP. In addition, strongholds for the new institutional practice were created by establishing PPP expertise centres within the various ministries. A crucial victory was Rijkswaterstaat's adoption-by its top-level management-of PPP as the default option for its construction projects (coined the 'Market unless' strategy) in 2004. Rijkswaterstaat transformed radically, changed internal structures and working procedures, and hired new staff with new skills. However, this victory for the pro-PPP coalition was accompanied by intensified bricolage activities. By establishing expertise centres in the different ministries, the new practice penetrated the domain of practitioners. At the same time this allowed for bricolage: the realization of a more tailor-made application of contractual PPP. The standard use of the European competitive dialogue to tender for DBFM(O) projects matched well the Rhinelandic habits of negotiation (Hoezen 2012). Rijkswaterstaat developed its own standard DBFM(O) contract, often leaving operations out of the contract, as it considered the operation of infrastructures as its core business. As Eversdijk and Korsten (2015) observed, in practice, often other types of contract were adopted, despite the outcomes of the PPCs.

In this period a number of large projects were contracted using DBFM contracts. So the process of institutional transplantation was advanced, PPP projects were started, enhancing the gaining of experience.

\subsection{Wave 4: institutional misfits become manifest and contested bricolage}

From 2011 onwards the Cabinet's priorities gave the institutionalization of PPPs another push forward. New DBFM(O) projects were initiated, and the domain in which PPP was being promoted was extended to other ministries and lower levels of government. Older PPP projects reached the maintenance and operation phases, opening up yet another frontier in the battle between those propagating new ways of working and those trying to bend these innovations to their familiar ways of doing things. The fact that outcomes of PPCs were not blindly followed shows that resistance to DBFM(O) contracts was sustained (Eversdijk and Korsten 2015). The conflicts that arose in several of the projects show that parties had problems aligning the Anglo-Saxon transplants with existing practices: the lack of 'goodness of fit' increasingly became apparent. In other projects, however, more favourable results were accomplished; it may be assumed that in these cases bricolage practices were more successful.

The problems reported by the Dutch Audit Office (2013) regarding the absence of firm contract management and the almost unrestrained number of contract changes can be perceived as indicators of bricolage: practitioners trying to bend the rigid contract conditions in order to cope with emerging tensions. These attempts at bricolage are contested. The coalition promoting $\operatorname{DBFM}(\mathrm{O})$ contracts persisted in exerting pressure on practitioners to comply with the Anglo-Saxon logic underlying these contracts. The Dutch Audit Office's plea for stricter contract management reveals its financial orientation and focus on the hard side of contracting typical of an Anglo-Saxon approach (Dutch Audit office 2013; Ministry of Finance 2014). A Rhinelandic take on these issues would emphasize the importance of soft factors like the quality of the relationship and adaptive management efforts, aimed at reconciling differences and coping with uncertainties (Weihe 2008; Hodge et al. 2010). The reply of the Ministry of Infrastructure and the Environment to the Audit Office report reflects that tradition. It states that it makes a distinction 
between reproachable and irreproachable shortcomings in performance when decisions have to be made regarding the imposition of sanctions (Dutch Audit Office 2013).

The initiative to agree upon a new market vision can also be seen as bricolage: parties acknowledged the misfit between orthodox Anglo-Saxon practices and the need to pay attention to the quality of collaboration and relationships (Minister of Infrastructure and the Environment 2016). In the Ministry of Finance's (2016) latest progress report, the Anglo-Saxon approach has nonetheless been preserved and extended to new domains such as contract management, given the emphasis on competition, value for money, performance, and standardization. On the other hand, in this report indications of bricolage can also be found: pragmatism, collaboration in developing opportunities for local differentiation, and enhancing learning among parties. Still, these two approaches entail contradictions, and it remains to be seen to what extent and how they will be successfully combined in the near future.

\section{5 | Bricolage over the years}

What does the above analysis tell us about the nature of institutional bricolage and its impact on the progress of the process of institutional transplantation? This contribution shows that the process developed stepwise, in fits and starts, due to practitioners' unwillingness to adopt the new practice. External, political pressure was needed to move the process further on-hence, the four waves of PPP project initiatives that we identified. However, bricolage was needed to make the steps a success. The first wave of PPP projects failed due to a lack of goodness of fit. During the second wave the lack of room for bricolage led to stagnation. In the third wave, penetration of contractual PPP into the world of practitioners went hand in hand with intensified bricolage. During the fourth wave the institutional misfit became apparent once more and the proclamation of the market vision can be seen as a farreaching bricolage effort, renegotiating mutual positions between protagonists of the Anglo-Saxon view of PPP, and practitioners, to get the process of institutional transplantation going again. This analysis shows that the process of institutional bricolage was not only made up of constructive negotiations, meaning making, and learning. We also saw the exercise of power, conflicts and competing coalitions, one led by the Ministry of Finance, promoting and defending the original transplant, and others resisting institutionalization or engaging in bricolage activities. It was the shifting power balance between these coalitions that determined the progress and shape of the institutionalization of the transplant. In addition, it can be observed that the process of institutional transplantation and bricolage was far from static. The 'original Anglo-Saxon approach to PPP' was only gradually defined and further developed and updated along the way. Also the institutional contexts in which PPP projects were initiated and realized underwent drastic adaptations: bricolage implies not only adaptation of the transplant to the new context, but also the other way around. It is a process of hybridization and transformation (Mukhtarov 2014). This creates path dependency, and leaving this pathway is increasingly difficult (Lowndes and Roberts 2013).

\section{5 | CONCLUSIONS}

We aimed to elucidate how and why contractual PPP as an Anglo-Saxon institutional transplant nested itself in the Dutch Rhinelandic context, what lessons our analysis offers for the transfer of DBFM(O) practices elsewhere, and the added value that this perspective brings to the policy transfer and the institutional transplantation literature. With regard to the developmental pathway of PPPs in the Netherlands, our analysis shows that the introduction of PPP into the Dutch context generated tensions and did not evolve in linear ways. At central government level, contractual PPPs surfaced and dominated further debates. The further diffusion of DBFM(O) contracts was characterized by ongoing struggles between a coalition of actors pushing the Anglo-Saxon-inspired DBFMO practices and practitioners in the various sectors resisting this institutional transplant. Hardboiled Anglo-Saxon contract practices emphasizing the tough side of contracting-such as competition, formal procedures, standardized tools, meeting 
performance targets, and strict contract management-clashed with Rhinelandic practices indulging in the soft side of contracting-dialogue, behaviour, good relationships, flexibility, and adaptive management.

Political support for contractual PPP was discontinuous, and a series of committees and reports was needed to reawaken political attention and push through its further adoption. In having to cope with the gradual but inevitable intrusion of contractual PPP, the resistant participants bent these ideas to align them with the requirements of existing Rhinelandic practices. So the step-wise institutionalization of the new transplant was accompanied by a simultaneous indigenization. However, on some occasions, the use of DBFM(O) contracts resulted in a decline in empathy among partners, higher levels of conflict, knowledge and other sources of influence shifting from the public to the private sector, and declining flexibility and willingness to compromise. Here, the Anglo-Saxon spirit seems to have displaced Rhinelandic practices (Streeck and Thelen 2005). Nevertheless, overall, the process of bricolage persisted, as for instance the recent initiative for the new market vision shows.

We conclude that the case shows that PPP innovation in the Netherlands can indeed be seen as a process of gradual but significant institutional transformation in which a foreign idea becomes local practice (Stone 2017). The theoretical contribution of this study is that it has infused the existing debate on the nature of policy transfer and institutional transplantation with findings regarding the process of bricolage as a non-linear process in which negotiation and learning go hand-in-hand with conflict and the exercise of power, resulting in a delicate equilibrium of conditions for mutual adaptation, without excluding potential shifts towards either displacement or elimination of the transplant. The claim that a new Anglo-Saxon institutional layer is grafted onto an old Rhinelandic practice may be correct if this idea of layering implies that the underlying layer still matters and both practices mingle, transforming both the transplant and old practices into something new (compare e.g., Streeck and Thelen 2005; Lowndes and Roberts 2013; Mukhtarov 2014).

What practical lessons can be drawn from this analysis? We suggest that the dualism that characterized the contractual PPP transplantation process in the Netherlands can be seen as a favourable condition that might be a best practice to be followed in transplantation processes elsewhere: forces holding each other in a dynamic equilibrium, combining drivers of institutional change (like the establishment of a supportive coalition and institutional strongholds) with the perseverance and enhancement of countervailing powers to allow for bricolage.

In this contribution, we have used the bricolage perspective to describe and interpret the introduction of contractual PPP in the Netherlands. In order to make generalizations, studies on other bricolage practices are needed, for instance aimed at the development of PPP in other countries. In addition to case studies, larger n-studies and comparative approaches are required. This would also contribute to the observed need to conduct international comparisons in the study of PPPs, which until now have predominantly focused on developments within specific countries (Hodge et al. 2010). As our study shows that the translation of Anglo-Saxon practices to the rather Anglophile Netherlands is complicated and not without problems, this may apply a fortiori to cases where this administrative divide is even wider. Delving more deeply into the nature and conditions of bricolage processes by further international comparative research may well be the way forward in making progress in both the field of PPP and that of policy transfer and institutional translation.

\section{ACKNOWLEDGMENTS}

This article was written in the context of the research project Governance for Smartening Public Private Partnerships (NWO-project number 409-14-014), financed by the Dutch Research Council (NWO), NSOB, Deltares, RebelGroup, ResetManagement, Twynstra Gudde, and Rijkswaterstaat. Additional support was received from the Delft Initiative for Mobility \& Infrastructures (DIMI).

\section{ORCID}




\section{REFERENCES}

Albert, M. (1991). Capitalisme Contre Capitalisme. Paris: Seuil.

Benson, D., \& Jordan, A. (2011). What have we learned from policy transfer research? Political Studies Review, 9, 366-378.

Bult-Spiering, M., \& Dewulf, G. (2008). Strategic issues in public-private partnerships: An international perspective. Oxford: Wiley.

Campbell, J. L. (2004). Institutional change and globalization. Princeton, NJ: Princeton University Press.

Campbell, J. L. (2009). Institutional reproduction and change. In G. Morgan, J. L. Campbell, C. Crouch, P. H. Kristensen, O. K. Pederson, \& R. Whitley (Eds.), The Oxford handbook of comparative institutional analysis (pp. 87-116). Oxford: Oxford University Press.

Commission for Private Financing of Infrastructure (2008). Op de goede weg en het juiste spoor [On the right track]. The Hague: Commissie Private Financiering van infrastructure. Retrieved from: https://www.google.nl/?gws_rd=ssl\#q= commissie+private+financiering+infratsructuur\&spf $=1495616490776$

De Jong, M. (1999). Institutional transplantation. Delft: Eburon Publishers.

De Jong, M. (2013). China's art of institutional bricolage. Policy \& Society, 32, 89-10.

De Jong, M., Lalenis, K., \& Mamadouh, V. (2002). The theory and practice of institutional transplantation. Dordrecht: Kluwer Academic Press.

Dolowitz, D., \& Marsh, D. (1996). Who learns what from whom: A review of the policy transfer literature. Political Studies, 44, 343-357.

Dolowitz, D., \& Marsh, D. (2000). Learning from abroad: The role of policy transfer in contemporary policy-making. Governance, 13, 5-23.

Dutch Audit Office (1993). Private financiering van de Wijkertunnel [Private financing of the Wijkertunnel], letter to Parliament, 2 June. The Hague: Dutch Audit Office.

Dutch Audit Office (2013). Contractmanagement bij DBFMO-projecten [Contract management of DBFMO projects]. The Hague: Tweede Kamer, vergaderjaar 2012-2013, 33 639, 2, 6 June.

Evans, M. (2009). Policy transfer in critical perspective. Policy Studies, 30, 243-268.

Evans, M., \& Davies, J. (1999). Understanding policy transfer: A multi-level, multi-disciplinary perspective. Public Administration, 77, 361-385.

Eversdijk, A., \& Korsten, A. (2015). Motieven en overwegingen achter publiek-private samenwerking [Motives and considerations underlying public-private partnerships]. Beleidsonderzoek online, February. doi: https://doi.org/10.5553/ beleidsonderzoek.000515

Ghobadian, A., Gallear, D., O'Regan, N., \& Viney, H. (Eds.) (2004). Public-private partnerships: Policy and experience. Basingstoke: Palgrave Macmillan.

Grimsey, D., \& Lewis, M. K. (2004). The governance of contractual relationships in public-private partnerships. Journal of Corporate Citizenship, 15, 91-109.

HM Treasury (2012). A new approach to public private partnerships. London: HM Treasury.

Hodge, G. A., Greve, C., \& Boardman, A. E. (Eds.) (2010). International handbook on public-private partnerships. Cheltenham: Edward Elgar.

Hoezen, M. E. L. (2012). The competitive dialogue procedure: Negotiations and commitment in inter-organisational construction projects. Enschede: University of Twente.

James, O., \& Lodge, M. (2003). The limitations of 'policy transfer' and 'lesson drawing' for public policy research. Political Studies Review, 1, 179-193.

Klijn, E.-H. (2009). Public-private partnerships in the Netherlands: Policy, projects and lessons. Economic Affairs, 29, $26-32$.

Knill, C. (2001). The Europeanisation of national administrations. Cambridge: Cambridge University Press.

Knowledge Centre PPP (Kenniscentrum PPS) (1998). Eindrapport Meer Waarde door SamenWerken [Final report on more value through collaboration]. The Hague: Ministry of Finance.

Knowledge Centre PPP (Kenniscentrum PPS) (1999, 2001, 2002, 2004). Voortgangsrapportage 1999, 2001, 2002, 2004 [Progress report 1999, 2001, 2002, 2004]. The Hague: Ministry of Finance.

Koppenjan, J. F. M. (2005). The formation of public-private partnerships: Lessons from nine transport infrastructure projects in the Netherlands. Public Administration, 83, 135-157.

Koppenjan, J. F. M., Mandell, M., Keast, R., \& Brown, K. (2010). Contexts, hybrids and network governance. In T. Bransen \& M. Holzer (Eds.), The future of governance (pp. 301-325). Newark, NJ: NCPP.

Lendvai, N., \& Stubbs, P. (2009). Assemblages, translation and intermediaries in South East Europe. European Societies, 11, 673-695.

Lodge, M. (2002). Institutional choice and policy transfer: Reforming British and German railway regulation. Governance, 16 , 159-178.

Lowndes, V., \& Roberts, M. (2013). Why institutions matter: The new institutionalism in political science. Basingstoke: Palgrave Macmillan.

Marsden, G., \& Stead, D. (2011). Policy transfer and learning in the field of transport: A review of concepts and evidence. Transport Policy, 18, 492-500. 
Minister of Infrastructure and the Environment (2016). Marktvisie Rijkswaterstaat en Bouwsector [The market vision of Rijkswaterstaat and the construction industry]. 11 April. Letter to Parliament. Retrieved from: https://www. rijksoverheid.nl/documenten/kamerstukken/2016/04/11/marktvisie-rijkswaterstaat-en-bouwsector

Ministry of Finance (2011). Visie of DBFM(O) [Vision of the Dutch government on DBFM(O)]. Letter of the Minister of Finance to the Chair of the Dutch parliament, FIN/2010/789 U, 8 March. The Hague: Ministry of Finance.

Ministry of Finance (2014, 2016). Voortgangsrapportage DBFM(O) 2015; 2016-2017 [Progress Report DBFM(O) 2015; 2016-2017]. 18 December 2014; 3 October 2016. The Hague: Ministry of Finance.

Ministry of Transport (2005). Resultaten taskforce PPS/Infrastructure [Results Taskforce PPP/Infrastructure]. Letter of the Minister of Transport to the Chair of the Dutch parliament, RWSSCD 2005/1427, 25 February. The Hague: Ministry of Transport.

Mukhtarov, F. (2014). Rethinking the travel of ideas: Policy translation in the water sector. Policy \& Politics, 42, 71-88.

National Audit Office (2001). Managing the relationship to secure a successful partnership in PFI projects. London: National Audit Office.

Osborne, S. P. (Ed.) (2000). Public-private partnerships: Theory and practice in international perspective. London: Routledge.

Parrado, S. (2008). Failed policies but institutional innovation through 'layering' and 'diffusion' in Spanish central administration. International Journal of Public Sector Management, 21, 230-252.

Reynaers, A. (2014). It takes two to tango: Public-private partnerships and their impact on public values. Amsterdam: Vrije Universiteit.

Rijkswaterstaat (2016). Samen met de markt [Together with the market]. The Hague: Rijkswaterstaat. Retrieved from: https://staticresources.rijkswaterstaat.nl/binaries/Samen\%20met\%20de\%20markt\%20-\%20strategische\% 20doorvertaling\%20Rijkswaterstaat\%201.1_tcm21-78981.pdf

Spackman, M. (2002). Public-private partnerships: Lessons from the British approach. Economic Systems, 26, $283-301$.

Stone, D. (2017). The transfer of policy failure: Bricolage, experimentalism and translation. Policy and Politics, 45, 55-70.

Streeck, W., \& Thelen, K. (2005). Beyond continuity: Institutional change in advanced political economies. Oxford: Oxford University Press.

Thelen, K. (2009). Institutional change in advanced political economies. British Journal of Industrial Relations, 47, 471-498.

Van der Schot, J., Van Beek, J., Ceton-O'Prinsen, N. M., \& Tan, G. L. (2003). Tunnels in Nederland [Tunnels in the Netherlands]. Utrecht: Bouwdienst Rijkswaterstaat.

Van Ham, J., \& Koppenjan, J. F. M. (2001). Building public-private partnerships: Assessing and managing risks in port development. Public Management Review, 3, 593-616.

Van Putten, J. (2013 [1982]). Policy styles in the Netherlands: Negotiation and conflict. In J. Richardson (Ed.), Policy styles in Western Europe (pp. 168-196). Abingdon: Routledge Revivals.

Verbraeken, H., \& Weissink, A. (2014). Nieuwe Botlek-brug zorgt voor grootste kostenoverschrijding A15-project [New bridge causes cost-overruns in A15 project], Het Financiele Dagblad, 10 July.

Verweij, S. (2015). Achieving satisfaction when implementing PPP transportation infrastructure projects: A qualitative comparative analysis of the A15 highway DBFM project. International Journal of Project Management, 33, 189-200.

Weihe, G. (2008). Ordering disorder-On the perplexities of the partnership literature. Australian Journal of Public Administration, 67, 430-442.

How to cite this article: Koppenjan J, and de Jong M. The introduction of public-private partnerships in the Netherlands as a case of institutional bricolage: The evolution of an Anglo-Saxon transplant in a Rhineland context. Public Admin. 2017;1-14. https://doi.org/10.1111/padm.12360 